\title{
KAJIAN SPASIAL TERHADAP POTENSI PEMANFAATAN JALUR PEDESTRIAN DI JALAN UTAMA KOTA PONTIANAK
}

\author{
Yudi Purnomo $^{1}$, Agustiah Wulandari ${ }^{2}$ \\ ${ }^{1}$ Program Studi Arsitektur Universitas Tanjungpura, Kota Pontianak \\ ${ }^{2}$ Program Studi Perencanaan Wilayah dan Kota \\ Universitas Tanjungpura, Kota Pontianak
}

Email korespondensi : yudipurnomo@teknik.untan.ac.id

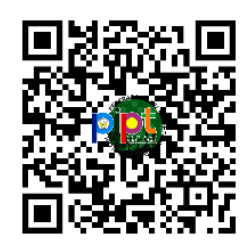

10.26418/pipt.2021.11

\begin{abstract}
Abstrak
Jalur pedestrian merupakan salah satu fasilitas bagi kegiatan atau pergerakan pejalan kaki. Pembangunan jalur pedestrian saat ini sedang dilaksanakan di sisi ruas jalan utama di Kota Pontianak. Pembangunan jalur pedestrian yang lebar, lengkap dengan atribut dan perabot dari sebuah fasilitas pejalan kaki, menjadi pemandangan baru di beberapa sudut kota. Kegiatan berjalan kaki di Kota Pontianak yang terletak di wilayah tropis khatulistiwa lembap menjadi tantangan tersendiri bagi keberhasilan pembangunan sebuah fasilitas pejalan kaki. Keberhasilan pembangunan akan dimaknai dengan tumbuhnya budaya berjalan kaki di fasilitas-fasilitas yang tersedia. Terdapat banyak faktor yang mempengaruhi keputusan bagi seseorang untuk memilih moda perjalanan, di antaranya adalah faktor waktu, kenyamanan, ketersediaan kendaraan bermotor dan pola tata guna lahan. Hal ini ditambah lagi oleh motivasi untuk melakukan kegiatan berjalan kaki, baik itu rekreatif, fungsional hingga yang pragmatis. Artikel ini bertujuan untuk menjelaskan potensi pemanfaatan jalur pedestrian di jalan utama Kota Pontianak, khususnya Jalan Ahmad Yani, dalam tinjauan teoritis spasial. Pembahasan menggunakan pendekatan kuasi kualitatif dengan menggunakan analisis spasial, yaitu radius perjalanan, street hits, dan walkscore. Perencanaan spasial yang heterogen dalam jarak jangkau pejalan kaki dan perencanaan lebar jalur pedestrian yang efektif dapat menjadi solusi peningkatan bangkitan pergerakan kawasan perkotaan di Kota Pontianak.
\end{abstract}

Kata kunci: jalur pedestrian, spasial, Kota Pontianak

\section{PENDAHULUAN}

Hampir seluruh komponen dan sudut pandang sebuah kota dapat dianalisis secara spasial (Weber, Tammi, Anderson, \& Wang, 2016). Blok terkecil di perkotaan hingga skala perkotaan serta wilayah pengaruhnya dapat menjadi obyek analisis. Banyak cara yang dapat dilakukan untuk menganalisis bentuk perkotaan dalam lingkup kota secara keseluruhan. Contohnya adalah analisis aksesibilitas dan keterhubungan pergerakan dan transportasi di perkotaan dalam hubungannya dengan tempat tinggal, tempat bekerja, dan atau kepadatan bangunan. Analisis spasial bertujuan untuk mempelajari dan memahami bagaimana pola serta struktur ruang perkotaan berhubungan dengan isu-isu strategis perencanaan seperti kesetaraan wilayah, daya saing dan daya tarik hingga kinerja lingkungan.

Salah satu pembentuk struktur perkotaan adalah jaringan jalan. Jaringan jalan memiliki fungsi sebagai jalur penghubung di dalam ruang perkotaan. Salah satu jalur penghubung tersebut adalah jalur pedestrian atau jalur bagi pejalan kaki. Sebagai salah satu komponen infrastruktur perkotaan, penyediaan fasilitas pejalan kaki secara umum menjadi bagian dari perancangan geometrik jalan. Keseimbangan interaksi antara pejalan kaki dan kendaraan, keamanan, kecukupan ruang, fasilitas yang menarik dan tersedianya fasilitas publik sebagai penunjang perlu dipertimbangkan dalam perencanaan fasilitas pejalan kaki (Shirvani, 1985)

Kegiatan pembangunan infrastruktur perkotaan menjadi pemandangan sehari-hari di perkotaan di seluruh dunia. Tidak terkecuali di Kota Pontianak yang menjadi Ibu Kota Provinsi Kalimantan Barat. Perencanaan dan pembangunan peningkatan jalur pedestrian saat ini sedang berlangsung dan mulai menghasilkan wajah baru perkotaan, khususnya di jalan-jalan utama 
Kota Pontianak. Pedestrian yang lebar dengan kelengkapan atribut dan perabotnya telah menjadi faktor pembangkit dan daya tarik bagi para pejalan kaki, baik bagi warga di sekitar jalur tersebut maupun bagi warga kota secara keseluruhan.

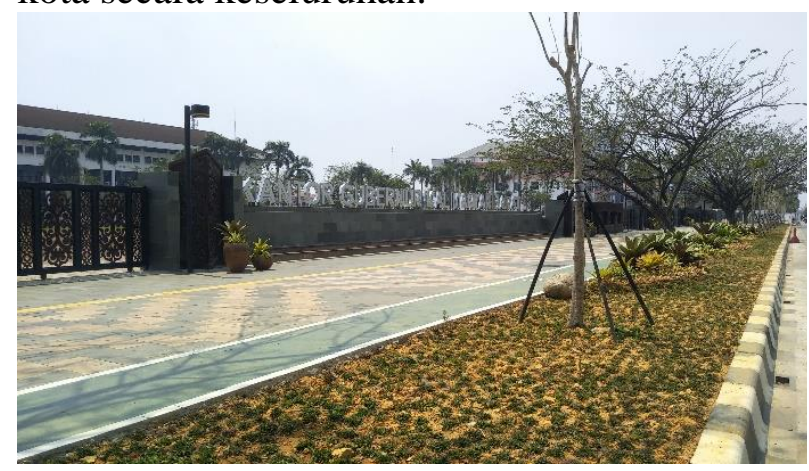

Sumber: (Dokumen Pribadi, 2021)

Gambar 1: Suasana Jalur Pedestrian di Jalan Ahmad Yani Kota Pontianak Setelah Selesai Pembangunan di Tahun 2021

Evaluasi terhadap sebuah perencanaan dan pembangunan tetap dilakukan untuk menjamin keberlangsungan sebuah fasilitas yang dibangun di perkotaan. Keberhasilan sebuah jalur pedestrian tidak saja dinilai dari perwujudan fisik. Jalur yang lebar dan kelengkapan fasilitas penunjang tidak akan memiliki makna tanpa hadirnya aktivitas berjalan kaki di kawasan tersebut. Bangkitan kegiatan pejalan kaki dengan berbagai aktivitasnya menjadi salah satu syarat keberhasilan sebuah jalur pedestrian.

Banyak faktor yang dapat meningkatkan bangkitan kegiatan dan pergerakan pejalan kaki. Salah satunya adalah kondisi spasial di wilayah tersebut, seperti bangunan dan aktivitas kegiatan di kawasan. Kondisi eksisting dari bangunan seperti luas lantai akan berkorelasi dengan jumlah populasi di dalam kawasan. Demikian halnya dengan fasilitas penunjang kawasan, seperti keberadaan restoran dan sistem transportasi kawasan, hingga faktor iklim setempat.

Artikel ini bertujuan untuk memberikan gambaran potensi sebuah jalur pedestrian di perkotaan melalui analisis spasial dari pola distribusi dan aksesibilitas fasilitas pelayanan atau aktivitas di perkotaan. Studi kasus untuk menjelaskan gambaran potensi jalur pedestrian di jalan utama Kota Pontianak adalah Jalan Ahmad Yani yang merupakan jalan arteri dan penghubung antar pola ruang perkotaan dengan dominasi peruntukan perkantoran, pendidikan, dan perdagangan.

\section{METODOLOGI}

Penelitian ini menggunakan pendekatan deskriptif kualitatif atau yang biasa disebut pula dengan kuasi kualitatif atau kualitatif semu. Secara umum penelitian belum didesain secara kualitatif secara menyeluruh, namun masih dipengaruhi oleh pendekatan kuantitatif dalam menempatkan teori pada data yang diperoleh. Pendekatan ini dalam teorinya menganut paham fenomenologi dan pos positivisme di mana paradigma kuantitatif mendasari pemikiran empirisme, idealisme, kritisme, vitalisme, humanistis dan rasionalisme (Bungin, 2010).

Studi kasus digunakan dalam proses penelitian untuk memusatkan penelitian pada suatu ruas jalan utama di Kota Pontianak, yaitu Jalan Ahmad Yani, namun tidak dimaksudkan untuk membuat sebuah generalisasi terhadap hasil studi. Format kuasi kualitatif lebih banyak menganalisis permukaan data namun mengadopsi cara berpikir induktif melalui penempatan teoriteori, dalam hal ini adalah teori tentang jalur pedestrian, pada data spasial yang diperoleh.

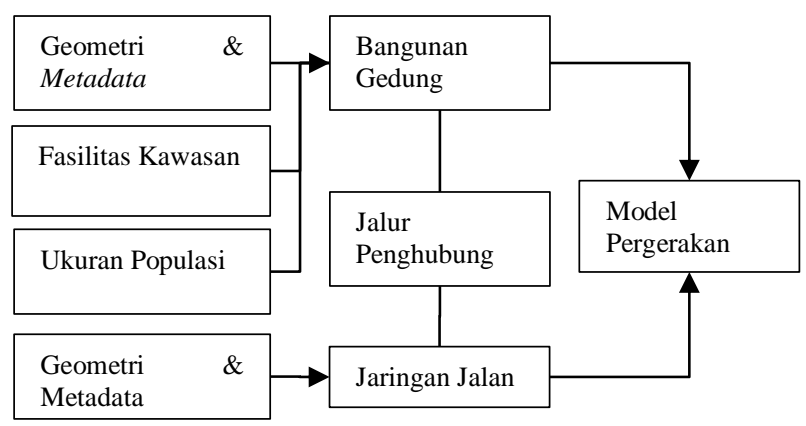

Sumber: (Dogan, Samaranayake, \& Saraf, 2018)

Gambar 2: Data Pemodelan Perangkat Urbano 


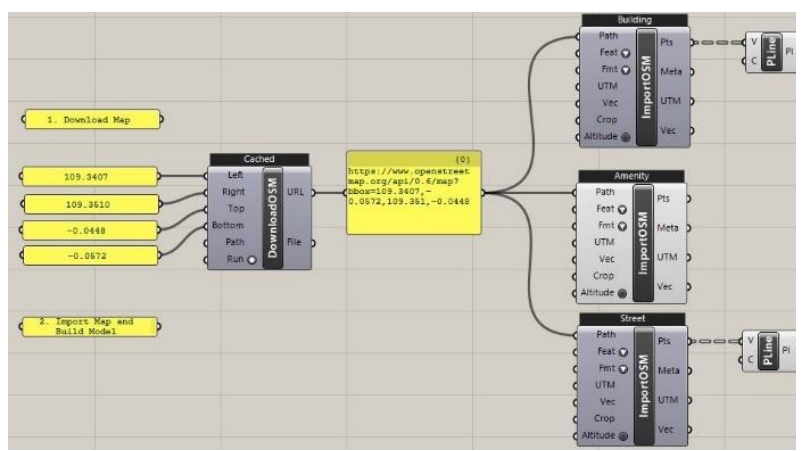

Sumber: (Analisis, 2021)

Gambar 3: Komponen/Parameter Unduh Peta OSM

Alat analisis yang digunakan dalam penelitian ini adalah Urbano, sebuah perangkat lunak untuk menghasilkan model, simulasi pergerakan, dan evaluasi aksesibilitas dari aktivitas/guna lahan (Tabel 1) dan transportasi. Perangkat ini memungkinkan pengambilan data GIS beserta metadata dilakukan secara sekunder dari OpenStreetMap.org menjadi sebuah model pergerakan perkotaan (Dogan, Yang, Samaranayake, \& Saraf, 2020). Tahapan pemodelan membangun sistem mobilitas dari data geometri dan metadata peta open source (diunduh pada saat penelitian dilakukan, lihat Gambar 1), yaitu jaringan jalan, bangunan gedung, dan fasilitas kawasan.

Tabel 1: Daftar Aktivitas Pelayanan

\begin{tabular}{|c|c|c|}
\hline SEKTOR & KOMPONEN & $\begin{array}{c}\text { AKTIVITAS } \\
\text { PELAYANAN }\end{array}$ \\
\hline \multirow[t]{5}{*}{ Kuliner } & \multirow[t]{3}{*}{ Restoran } & Restoran \\
\hline & & Cafe \\
\hline & & Bar \\
\hline & \multirow[t]{2}{*}{ Grosir } & Toko bahan makanan \\
\hline & & Toko serba ada \\
\hline \multirow{5}{*}{$\begin{array}{l}\text { Budaya } \\
\text { dan } \\
\text { Rekreasi }\end{array}$} & \multirow[t]{2}{*}{ Kebugaran } & Fitness Center/Gym \\
\hline & & Kolam Renang \\
\hline & \multirow[t]{3}{*}{ Kesenian } & Sinema \\
\hline & & Theatre \\
\hline & & Perpustakaan \\
\hline \multirow[t]{3}{*}{ Kesehatan } & \multirow[t]{3}{*}{ Kesehatan } & Rumah Sakit \\
\hline & & Klinik \\
\hline & & Apotek \\
\hline \multirow[t]{4}{*}{ Pendidikan } & \multirow[t]{4}{*}{ Pendidikan } & TK \\
\hline & & Sekolah Menengah \\
\hline & & Sekolah Lanjutan \\
\hline & & Perguruan Tinggi \\
\hline \multirow[t]{3}{*}{ Komersial } & \multirow{2}{*}{$\begin{array}{l}\text { Bank dan } \\
\text { ATM }\end{array}$} & Bank \\
\hline & & ATM \\
\hline & Kantor Pos & Kantor Pos/Kios \\
\hline
\end{tabular}

Sumber: (Weber, Tammi, Anderson, \& Wang, 2016)
Ada tiga pengukuran pergerakan yang dihasilkan dalam proses analisis, yaitu (Dogan, Samaranayake, \& Saraf, 2018):

a. Walkscore, yaitu pengukuran pergerakan dengan skor 0 s.d. 100 didasarkan kepada kedekatan dengan fasilitas layanan, seperti pertokoan, restoran/rumah makan, bank, warung kopi, dan lain-lain, serta memberikan nilai lebih pada persimpangan jalan. Walkscore juga dikembangkan untuk mengevaluasi kemampuan berjalan kaki lingkungan dalam konteks jaringan terhadap jumlah fasilitas pelayanan lingkungan.

b. Jumlah pejalan kaki (street hits) di masing-masing jalan. Memungkinkan untuk memperhitungkan potensi penggunaan jalan oleh pedestrian yang dipengaruhi oleh jumlah bangunan, populasi pengguna dan fasilitas pelayanan.

c. Jarak/waktu jangkauan, yaitu jarak atau waktu untuk menghubungkan daerah asal dan tujuan pergerakan berdasarkan sistem jaringan.

\section{Jalur Pedestrian}

Pedestrian memiliki arti pejalan kaki (Wardhono, 2009). Pejalan kaki adalah setiap orang yang berjalan di ruang lalu lintas jalan, baik dengan maupun tanpa alat bantu (Perencaaan Teknis Fasilitas Pejalan Kaki, 2018). Fasilitas pejalan kaki adalah fasilitas pada ruang milik jalan yang disediakan untuk pejalan kaki, antara lain dapat berupa trotoar, penyeberangan jalan di atas jalan (jembatan), pada permukaan jalan dan di bawah jalan (terowongan) (Perencaaan Teknis Fasilitas Pejalan Kaki, 2018). Jalur pedestrian merupakan sarana infrastruktur fisik berupa jalan/jalur yang diperuntukkan bagi aktivitas berjalan seseorang/pejalan kaki (Sakinah, Kusuma, Tampubolon, \& Prakarso, 2018).

Kegiatan pejalan kaki di suatu ruas jalan menurut Rapoport (1983) dalam Tanan (2011) dikategorikan menjadi kegiatan dinamis dan statis. Kegiatan dinamis berupa kegiatan berjalan kaki, berlari, dan berjalan- 
jalan, sedangkan kegiatan statis berupa kegiatan berdiri, bersender, duduk, berjongkok atau berbaring. Selain itu kegiatan pejalan kaki memiliki kelebihan dalam hal pengamatan terhadap lingkungan di mana pejalan kaki berkegiatan, lebih detail dan bebas melakukan kontak dengan lingkungannya. Kegiatan pejalan kaki menjadi bagian penting dalam sistem transportasi dan keterpaduannya dengan sistem tata ruang wilayah (Tanan, 2011).

Waktu, kenyamanan, ketersediaan kendaraan bermotor dan pola tata guna lahan menjadi faktor yang mempengaruhi jarak tempuh seseorang untuk berjalan kaki (Untermann dalam Tanan, 2011). Kecenderungan jarak yang lebih jauh dan waktu yang lama adalah pilihan untuk pejalan kaki yang berekreasi dan berbelanja, namun tidak untuk keperluan bekerja. Ketersediaan koridor dengan peneduh dari kondisi iklim dan perencanaan transportasi umum yang baik akan mendorong seseorang lebih aktif berjalan kaki. Selanjutnya pola tata guna lahan yang homogen menjadi salah satu resistan seseorang untuk berjalan kaki.

Beberapa studi tentang tujuan perjalanan yang disampaikan oleh Tanan (2011), menyatakan bahwa tujuan perjalanan bagi pejalan kaki lebih banyak (>14\%) untuk tujuan urusan personal, berbelanja, sosial/rekreasi dan sekolah. Sedangkan untuk tujuan seperti bekerja atau terkait pekerjaan cukup kecil menjadi pembangkit seseorang untuk berjalan kaki $(<8 \%)$. Selain itu terdapat tujuan dominan bagi pejalan kaki lainnya adalah menuju pemberhentian angkutan umum, tujuan kesehatan ataupun tujuan penghematan menjadi alasan seseorang berjalan kaki.

Berdasarkan waktu dan tujuan berjalan kaki, manusia dibedakan menjadi tiga (Tisnaningtyas, 2015), yaitu: berjalan kaki dengan tujuan fungsional, perjalanan tidak terikat waktu, dan untuk keperluan rekreasi yang dilakukan sewaktu-waktu. Perjalanan fungsional dimaksudkan untuk pergi ke tempat kerja atau yang sifatnya reguler. Perjalanan tidak terikat waktu seperti berbelanja dengan berjalan santai dengan kecepatan rendah dan jarak lebih panjang. Sedangkan perjalanan rekreasi dilakukan dengan santai, menikmati pemandangan dan juga kegiatan statis lainnya.

Terdapat empat alasan seseorang berjalan kaki, yaitu pencapaian, visual, kesehatan dan efisiensi. Keempat alasan ini kemudian di ringkas kembali menjadi tiga kelompok, yaitu rekreatif, fungsional dan pragmatis (Sakinah, Kusuma, Tampubolon, \& Prakarso, 2018). Rekreatif dimaksudkan kegiatan yang bersifat penyegaran kembali badan dan pikiran, seperti menikmati pemandangan dan suasana kota. Kelompok fungsional dimaksudkan untuk kegiatan yang terkait dengan kesehatan dan efisiensi waktu dan biaya. Sedangkan kelompok pragmatis memiliki alasan pencapaian sebuah tempat atau tujuan, seperti jarak dekat, pindah moda transportasi dan aksesibilitas. Kelompok pragmatis cenderung melakukan perjalanan jarak pendek dibandingkan dengan kelompok fungsional dan rekreatif.

\section{Karakteristik Pejalan Kaki}

Menurut Tanan (2011) dalam buku Fasilitas Pejalan Kaki membagi karakteristik pejalan kaki menjadi empat kategori, yaitu berdasarkan kecepatan berjalan, kebutuhan ruang, jarak berjalan, dan pejalan kaki yang berkebutuhan khusus. Kategori kecepatan berjalan dan jarak berjalan menjadi kategori yang memiliki keterkaitan yang erat dengan kondisi spasial dalam hal tata guna lahan.

Tabel 2: Kecepatan Pejalan Kaki dan Tata Guna Lahan

\begin{tabular}{|c|l|c|}
\hline NO & TATA GUNA LAHAN & $\begin{array}{c}\text { KECEPATAN } \\
(\mathrm{m} / \mathrm{det})\end{array}$ \\
\hline 1 & Perdagangan & $1,07-1,31$ \\
\hline 2 & Perkantoran & $1,13-1,31$ \\
\hline 3 & Kesehatan & $1,07-1,59$ \\
\hline 4 & Pendidikan & 1,16 \\
\hline
\end{tabular}

Sumber: (Tanan, 2011)

Kecepatan pejalan kaki normal rata-rata adalah 1,32 m/det, sedangkan di kerumunan berkisar 1,01 m/det. Berbeda ketika kondisi menanjak, kecepatan pejalan kaki berada di kisaran $0,88 \mathrm{~m} /$ det. Kecepatan ketika berlari 
adalah yang tercepat dengan rata-rata 2,38 $\mathrm{m} /$ det. Selain itu kecepatan pejalan kaki juga dipengaruhi oleh gender dan usia. Rata-rata pejalan kaki tercepat dilakukan oleh remaja dengan rata-rata $1,79 \mathrm{~m} /$ det dan paling rendah oleh anak-anak dengan rata-rata $1,12 \mathrm{~m} / \mathrm{det}$ atau wanita bersama anak-anak di kecepatan 0,72 m/det (Tanan, 2011).

Tabel 2 menjelaskan kecepatan perjalanan berdasarkan tata guna lahan berada di kecepatan rata-rata pejalan kaki dalam kondisi normal, yaitu direntang 1,07 $\mathrm{m} /$ det s.d. $1,59 \mathrm{~m} /$ det. Tata gula lahan dengan fungsi kesehatan mendorong pejalan kaki berjalan lebih cepat yaitu $1,59 \mathrm{~m} / \mathrm{det}$, namun tata guna lahan dengan fungsi kesehatan dan perdagangan juga menjadi fungsi dengan kecepatan rata-rata terendah.

Karakteristik pejalan kaki juga dipengaruhi oleh jarak tempuh yang sangat tergantung kepada tujuan perjalanan. Taman umum menjadi jarak terjauh yang dijangkau oleh pejalan kaki, yaitu bisa sampai 60 menit perjalanan. Sedangkan pasar lokal dan sekolah dasar menjadi jarak terpendek tujuan perjalanan, yaitu kurang lebih 10 menit. Hal ini lebih lanjut dapat dijelaskan dalam Tabel 3.

Tabel 3: Jarak Berjalan Kaki Sesuai Tujuan Perjalanan

\begin{tabular}{|c|l|c|}
\hline NO & \multicolumn{1}{|c|}{ PRASARANA } & $\begin{array}{c}\text { JARAK DARI } \\
\text { TEMPAT TINGGAL }\end{array}$ \\
\hline 1 & Pusat tempat kerja & 20 sampai 30 menit \\
\hline 2 & Pusat kota (pasar dsb) & 30 sampai 45 menit \\
\hline 3 & Pasar lokal & $0,75 \mathrm{~km}$ atau 10 menit \\
\hline 4 & Sekolah dasar & $0,75 \mathrm{~km}$ atau 10 menit \\
\hline 5 & $\begin{array}{l}\text { Sekolah menengah } \\
\text { pertama }\end{array}$ & $1,5 \mathrm{~km}$ atau 20 menit \\
\hline 6 & Sekolah lanjutan atas & 20 sampai 30 menit \\
\hline 7 & $\begin{array}{l}\text { Tempat bermain } \\
\text { anak/taman lokal }\end{array}$ & $0,75 \mathrm{~km}$ atau 20 menit \\
\hline 8 & $\begin{array}{l}\text { Tempat olah raga dan } \\
\text { pusat rekreasi }\end{array}$ & $1,5 \mathrm{~km}$ atau 20 menit \\
\hline 9 & $\begin{array}{l}\text { Taman untuk } \\
\text { umum/cagar (kebun } \\
\text { binatang dsb) }\end{array}$ & 30 sampai 60 menit \\
\hline
\end{tabular}

Sumber: (Tanan, 2011)

Jarak rata-rata yang masih sanggup ditempuh pejalan kaki untuk kondisi di Indonesia adalah kurang lebih 500 meter. Sedangkan jarak umum seseorang mau berjalan kaki berkisar antara 300 sampai 400 meter atau yang terjauh bisa sampai 1,6 km. Namun untuk seseorang yang berkebutuhan khusus jarak 50-200 meter masih dapat ditoleransi (Tanan, 2011).

\section{Fasilitas Pejalan Kaki}

Aktivitas berjalan dapat meningkatkan penghematan terhadap biaya transportasi warga kota maupun peningkatan infrastruktur transportasi pemerintah, menghidupkan komunitas, meningkatkan status kesehatan warga dan mendukung pembangunan ekonomi kota, guna lahan dan menegakkan keadilan sosial (Tanan, 2011). Terdapat dua model kebijakan bagi pengembangan fasilitas pejalan kaki, yaitu new urbanism dan complete street. Model new urbanism menekankan penempatan fasilitas bagi pejalan kaki untuk aktivitas bekerja dapat diakses dalam waktu 10 menit, perancangan yang ramah terhadap pejalan kaki dan bebas dari kendaraan bermotor pada waktu yang ditetapkan. Sedangkan model complete street memiliki konsep bahwa jalan lokal menjadi lengkap jika memberikan kesempatan yang sama bagi seluruh moda transportasi, termasuk berjalan dan bersepeda (Tanan, 2011).

Di Indonesia penyediaan fasilitas bagi pejalan kaki di atur dalam UU Nomor 26 Tahun 2007 tentang Penataan Ruang dan UU No.22 Tahun 2009 tentang Lalu Lintas dan Angkutan Jalan. Pasal 28 ayat b UU 26 tahun 2007 menyatakan bahwa rencana penyediaan dan pemanfaatan prasarana dan sarana pejalan kaki dimaksudkan untuk menjalankan fungsi wilayah kota sebagai pusat pelayanan sosial ekonomi dan pusat pertumbuhan wilayah. Fasilitas untuk pejalan kaki juga menjadi kelengkapan wajib untuk setiap jalan yang digunakan untuk lalu lintas umum, berupa trotoar, tempat penyeberangan dan fasilitas lain (Pasal 25 UU 22 Tahun 2009).

Secara teknis ketentuan perencanaan fasilitas pejalan kaki diatur juga dalam Pedoman Perencanaan Teknis Fasilitas Pejalan Kaki (SE Menteri PUPR Nomor 
02/SE/M/2018 tanggal 28 Februari 2018). Perencanaan fasilitas pejalan kaki harus memenuhi prinsip umum:

a. aspek keterpaduan sistem; penataan lingkungan, sistem transportasi, dan aksesibilitas antar kawasan;

b. aspek kontinuitas; menghubungkan tempat asal-tujuan;

c. aspek keselamatan, keamanan, dan kenyamanan;

d. aspek aksesibilitas; dapat diakses seluruh pengguna.

dan prinsip teknis:

a. memenuhi kebutuhan kapasitas;

b. memenuhi ketentuan kontinuitas dan persyaratan teknis aksesibilitas;

c. konstruksi yang memenuhi syarat keamanan dan mudah dalam pemeliharaan.

\section{Desain Trotoar}

Lebar efektif minimum ruang pejalan kaki berdasarkan kebutuhan adalah $60 \mathrm{~cm}$ ditambah $15 \mathrm{~cm}$. Lebar minimum jalur pejalan kaki secara ideal diperoleh dengan menggunakan rumus (Perencaaan Teknis Fasilitas Pejalan Kaki, 2018):

$w=\frac{v}{35}+N$

$\mathrm{w}=$ lebar jalur pejalan kaki

$\mathrm{v}=$ volume pejalan kaki (orang/menit/meter) $\mathrm{N}=$ lebar tambahan $(0,5$, bangkitan pejalan kaki rendah, 1 bangkitan sedang, dan 1,5 untuk bangkitan tinggi)

Arus pejalan kaki berupa daerah pasar atau terminal berkisar lebih dari 33 orang/menit/meter, daerah perbelanjaan bukan pasar sekitar 16-33 orang/menit/meter, dan kurang dari 16 orang/menit/meter untuk daerah lainnya. Arus pejalan kaki dapat dilihat dalam Tabel 3. Lebar jalur pejalan kaki masih ditambah lagi jika terdapat perlengkapan jalan seperti patok rambu lalu lintas, pohon peneduh atau fasilitas lain seperti kursi roda. Jika jalur digunakan bersama dengan jalur sepeda, maka tetap menyediakan lebar minimal trotoar bagi pejalan kaki sebesar 1,5 meter.

Tabel 4: Arus dan Lebar Efektif Maksimum

\begin{tabular}{|c|c|c|c|}
\hline LOKASI & $\begin{array}{c}\text { TATA } \\
\text { GUNA } \\
\text { LAHAN }\end{array}$ & $\begin{array}{c}\text { ARUS } \\
\text { PEJALAN } \\
\text { KAKI } \\
\text { MAKSIMUM } \\
\text { (pejalan } \\
\text { kaki/menit) } \\
\end{array}$ & $\begin{array}{c}\text { LEBAR } \\
\text { EFEKTIF } \\
\text { MASKSIMUM } \\
(\mathrm{m})\end{array}$ \\
\hline $\begin{array}{l}\text { Jalan } \\
\text { Arteri - } \\
\text { Pusat } \\
\text { kota } \\
\text { (CBD) }\end{array}$ & $\begin{array}{l}\text { Taman, } \\
\text { sekolah, } \\
\text { pusat } \\
\text { pembangkit } \\
\text { pejalan } \\
\text { kaki utama } \\
\text { lainnya }\end{array}$ & 80 & 2,75 s.d. 3,75 \\
\hline $\begin{array}{c}\text { Jalan } \\
\text { Kolektor } \\
\text { - Pusat } \\
\text { kota } \\
\text { (CBD) }\end{array}$ & $\begin{array}{l}\text { Taman, } \\
\text { sekolah, } \\
\text { pusat } \\
\text { pembangkit } \\
\text { pejalan } \\
\text { kaki utama } \\
\text { lainnya }\end{array}$ & 60 & 2 s.d. 2,75 \\
\hline $\begin{array}{l}\text { Jalan } \\
\text { Lokal }\end{array}$ & & 50 & 1,9 \\
\hline $\begin{array}{l}\text { Jalan } \\
\text { Lokal } \\
\text { dan } \\
\text { Lingkun } \\
\text { gan } \\
\end{array}$ & $\begin{array}{l}\text { Wilayah } \\
\text { perumahan }\end{array}$ & 35 & 1,5 \\
\hline
\end{tabular}

Sumber: (Perencaaan Teknis Fasilitas Pejalan Kaki, 2018)

Tabel 5: Fungsi Jalan dan Jenis Jalur Pejalan Kaki

\begin{tabular}{|c|l|l|l|}
\hline $\begin{array}{c}\text { FUNGSI } \\
\text { JALAN }\end{array}$ & $\begin{array}{c}\text { SISTEM } \\
\text { JALAN }\end{array}$ & $\begin{array}{c}\text { BATAS } \\
\text { KECEPATAN }\end{array}$ & $\begin{array}{l}\text { JENIS JALUR } \\
\text { PEDESTRIAN }\end{array}$ \\
\hline $\begin{array}{l}\text { Arteri \& } \\
\text { Kolektor }\end{array}$ & Primer & s.d. $80 \mathrm{~km} / \mathrm{jam}$ & $\begin{array}{l}\text { Trotoar } \\
\text { berpagar } \\
\text { dengan akses } \\
\text { pada } \\
\text { penyeberangan } \\
\text { dan halte bus }\end{array}$ \\
\hline Lokal & Primer & s.d. $30 \mathrm{~km} / \mathrm{jam}$ & Trotoar \\
\hline $\begin{array}{c}\text { Arteri \& } \\
\text { Kolektor }\end{array}$ & Sekunder & s.d. $30 \mathrm{~km} / \mathrm{jam}$ & $\begin{array}{l}\text { Trotoar atau } \\
\text { bahu } \\
\text { diperkeras }\end{array}$ \\
\hline Lokal & Sekunder & s.d. $30 \mathrm{~km} / \mathrm{jam}$ & Trotoar \\
\hline
\end{tabular}

Sumber: (Perencaaan Teknis Fasilitas Pejalan Kaki, 2018)

Skema proses penyediaan fasilitas pejalan kaki dalam Pedoman Perencanaan Teknis Fasilitas Pejalan Kaki disebutkan pula jika volume pejalan kaki maksimum kurang dari 10 pejalan kaki/menit, maka direncanakan fasilitas pejalan kaki minimum dengan lebar 0,75 meter. Sedangkan jika lebih dari 10 pejalan kaki/menit mengacu kepada Rumus 1 dan Tabel 3. 


\section{HASIL DAN PEMBAHASAN}

Jalan Ahmad Yani Kota Pontianak memiliki panjang kurang lebih 4,8 km. Jalan ini merupakan jalan utama penghubung dari pusat kota ke arah timur dan melalui Jalan Arteri Supadio/Ahmad Yani 2 terhubung dengan Bandara Supadio. Pembahasan dilakukan dengan membagi jalan ini menjadi tiga segmen (Gambar 5), yaitu:

a. Segmen 1, merupakan penggalan Jalan Ahmad Yani dari perempatan Jalan Sultan Syarif Abdurrahman dan Jalan Gusti Sulung Lelanang sampai dengan simpang Jalan Sutoyo dan Jalan Veteran (Gambar 6).

b. Segmen 2, merupakan penggalan Jalan Ahmad Yani dari simpang Jalan Sutoyo dan Jalan Veteran sampai dengan Bundaran Universitas Tanjungpura (Jalan Daya Nasional - Jalan Prof. Dr. H. Hadari Nawawi) (Gambar 7); dan

c. Segmen 3, merupakan penggalan kawasan Jalan Ahmad Yani dari Bundaran Universitas Tanjungpura (Jalan Daya Nasional - Jalan Prof. Dr. H. Hadari Nawawi) sampai dengan Simpang Jalan Sungai Raya Dalam (Bangunan Gedung Kantor Mapolda Kalimantan Barat) (Gambar 8).

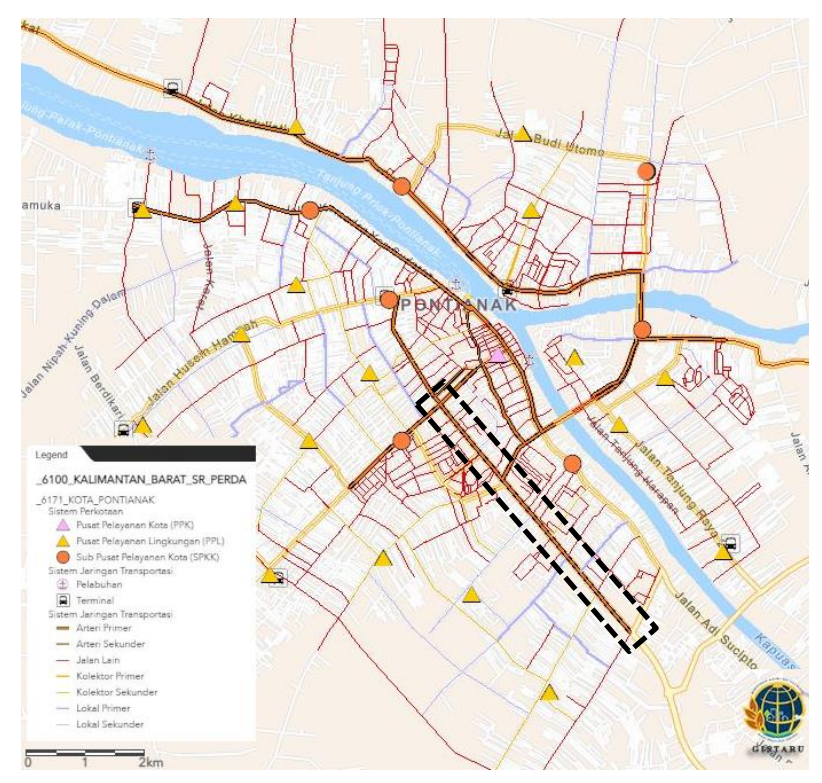

Sumber: (gistaru.atrpbn.go.id, 2021)

Gambar 4: Gambar Struktur Ruang Kota Pontianak

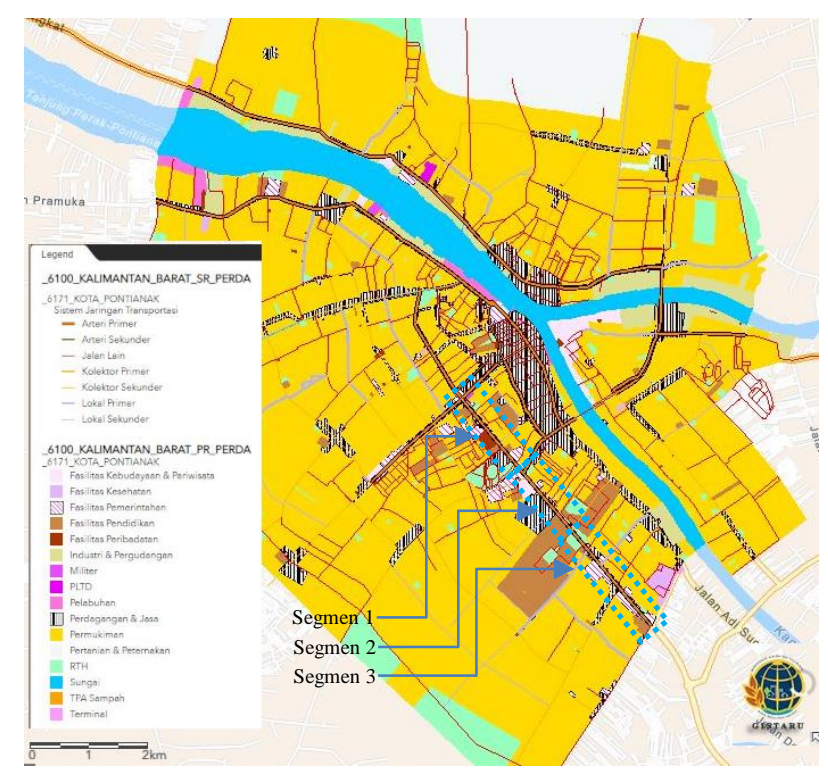

Sumber: (gistaru.atrpbn.go.id, 2021)

Gambar 5: Gambar Pola Ruang Kota Pontianak

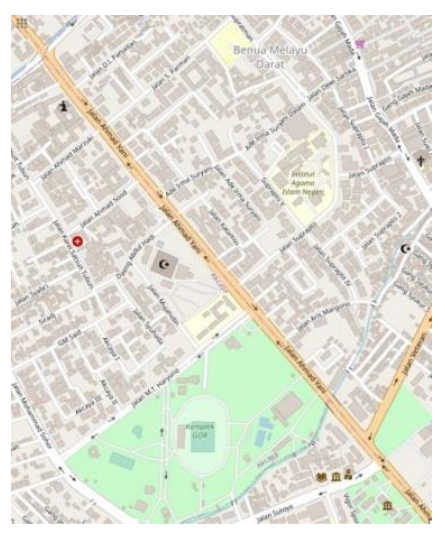

Sumber: (openstreetmap.org, 2021) Gambar 6: Peta Dasar Segmen 1

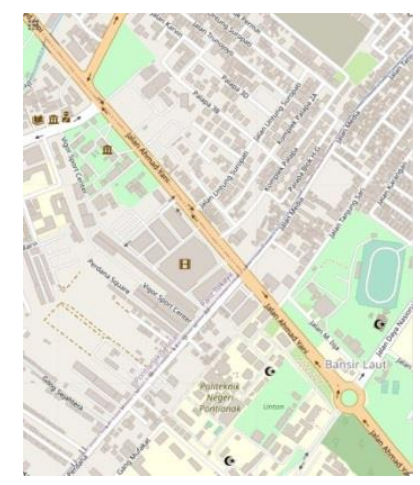

Sumber: (openstreetmap.org, 2021) Gambar 7: Peta Dasar Segmen 2 


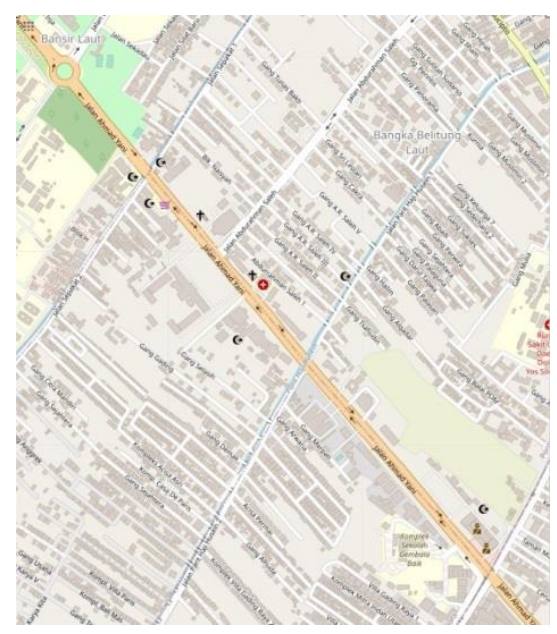

Sumber: (openstreetmap.org, 2021)

Gambar 8: Peta Dasar Segmen 3

\section{Radius Perjalanan}

Radius perjalanan bagi pejalan kaki dihasilkan berdasarkan analisis jarak jangkau pejalan kaki berdasarkan titik asal fasilitas aktivitas kawasan (amenities). Jarak jangkau dianalisis menggunakan acuan jarak jangkau pejalan kaki berkebutuhan khusus dengan toleransi maksimum 200 meter hingga dan jarak maksimum pejalan kaki normal sejauh 500 meter. Titik asal dan tujuan perjalanan dapat dilihat dalam gambar hasil analisis di bawah ini.

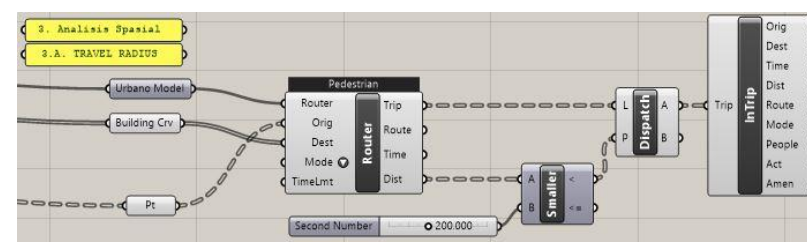

Sumber: (Analisis, 2021)

Gambar 9: Komponen/Parameter Radius Perjalanan

Jarak perjalanan terhadap lokasi fasilitas aktivitas pelayanan terhadap jalur pedestrian di sepanjang Jalan Ahmad Yani bagi pejalan kaki berkebutuhan khusus cukup sulit dijangkau. Gambar 10, Gambar 12, dan Gambar 14 memperlihatkan hanya beberapa fasilitas pelayanan dan kegiatan (amenities) yang cukup terjangkau dari jalur pedestrian (garis biru). Sebagian fasilitas yang terjangkau dari jalur pedestrian tersebut berada di sisi selatan jalan.

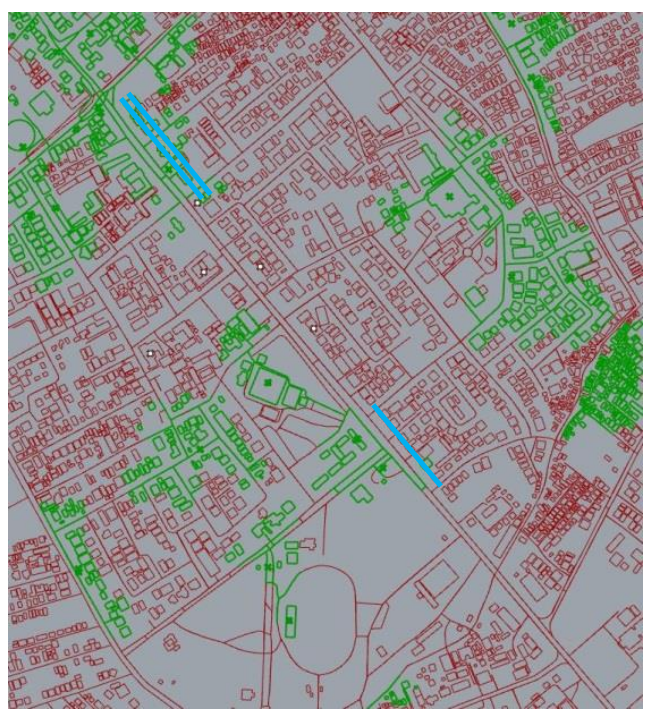

Sumber: (Analisis, 2021)

Gambar 10: Radius Perjalanan Segmen 1, Jarak Maksimum 200 meter

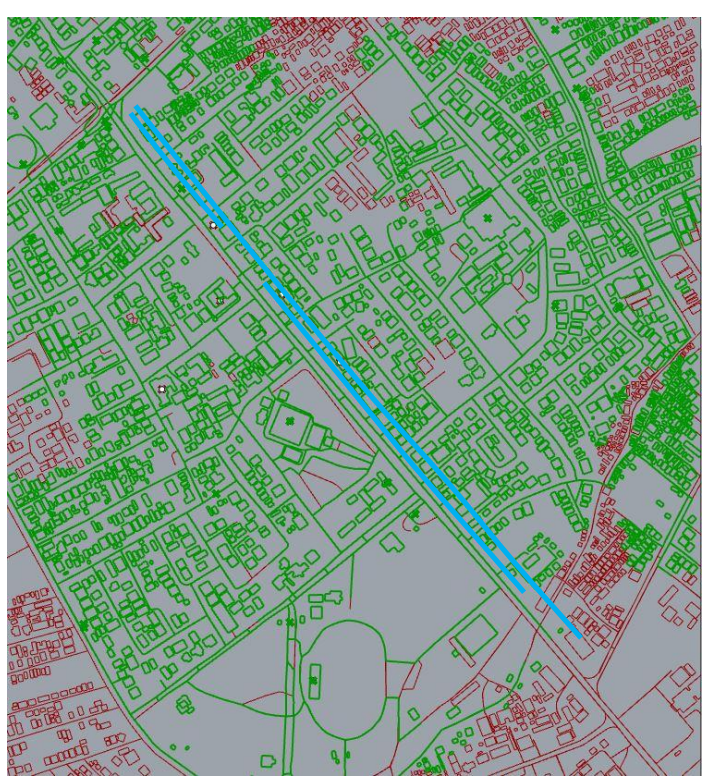

Sumber: (Analisis, 2021)

Gambar 11: Radius Perjalanan Segmen 1, Jarak Maksimum 500 meter

Keterjangkauan jalur pedestrian dalam jarak maksimum dari fasilitas aktivitas dan kegiatan pelayanan terlihat dapat dalam Gambar 11, Gambar 13, dan Gambar 15. Potensi jalur pedestrian terlihat hampir melayani sepanjang jalan di ketiga segmen. Di Segmen 1 potensi layanan berada di dua sisi jalan, baik sisi utara maupun sisi selatan. Potensi ini memang didukung oleh keberadaan fasilitas aktivitas layanan seperti tempat ibadah, sekolah dan olah raga di sisi selatan serta fasilitas seperti bank/ATM dan 
restoran dan beberapa layanan komersial berada di sisi sebelah utara jalan. Namun di Segmen 2 terlihat potensi layanan jalur pedestrian lebih dominan di sisi bagian selatan. Hal ini dikarenakan beberapa fasilitas/aktivitas layanan memang berada di sisi ini, seperti fungsi komersial dan budaya/hiburan.

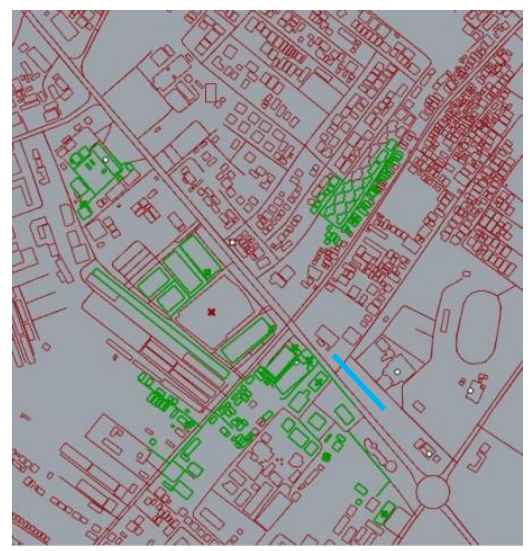

Sumber: (Analisis, 2021)

Gambar 12: Radius Perjalanan Segmen 2, Jarak Maksimum 200 meter

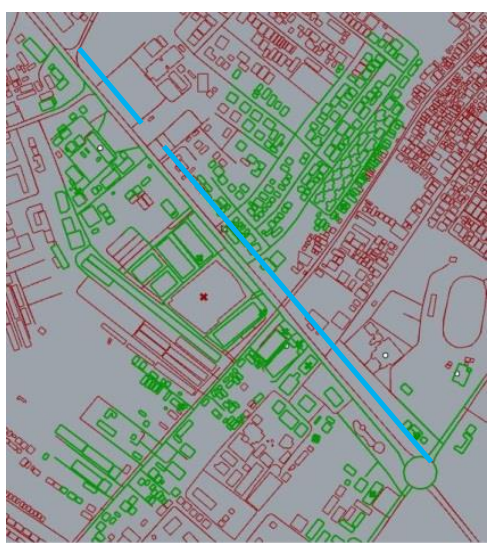

Sumber: (Analisis, 2021)

Gambar 13: Radius Perjalanan Segmen 2, Jarak Maksimum 500 meter

Berbeda dengan Segmen 1 dan Segmen 2, Segmen 3 secara fungsional, kawasan lebih didominasi oleh fungsi perkantoran, sehingga sebaran fasilitas aktivitas pelayanan tidak banyak terlihat di kawasan ini. Potensi jalur pedestrian di Jalan Ahmad Yani berada di sisi utara dan selatan jalan relatif di bagian tengah segmen. Hal ini dikarenakan pada bagian tersebut terdapat area komersial, fasilitas kesehatan dan beberapa restoran atau tempat makan.

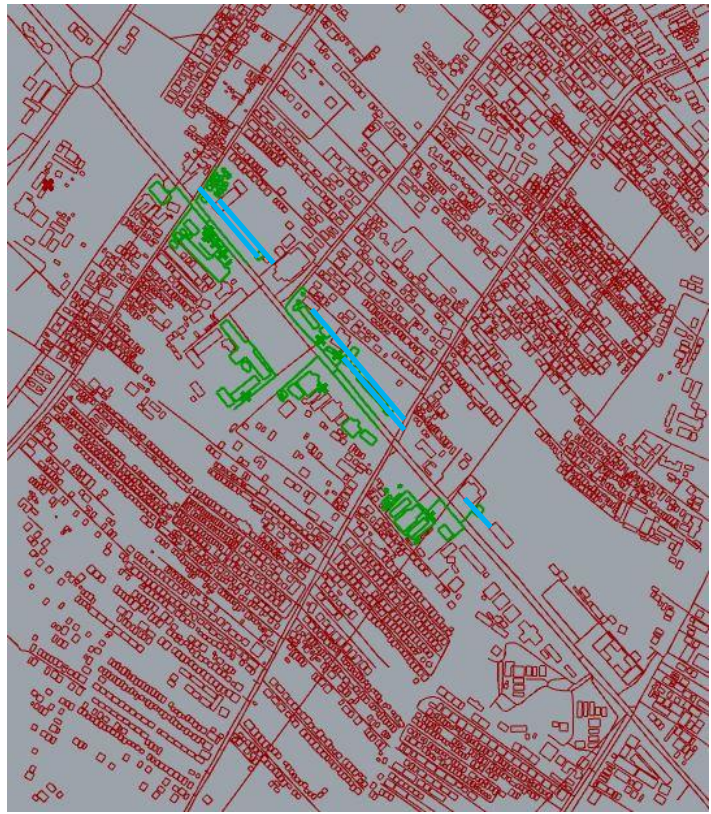

Sumber: (Analisis, 2021)

Gambar 14: Radius Perjalanan Segmen 3, Jarak Maksimum 200 meter

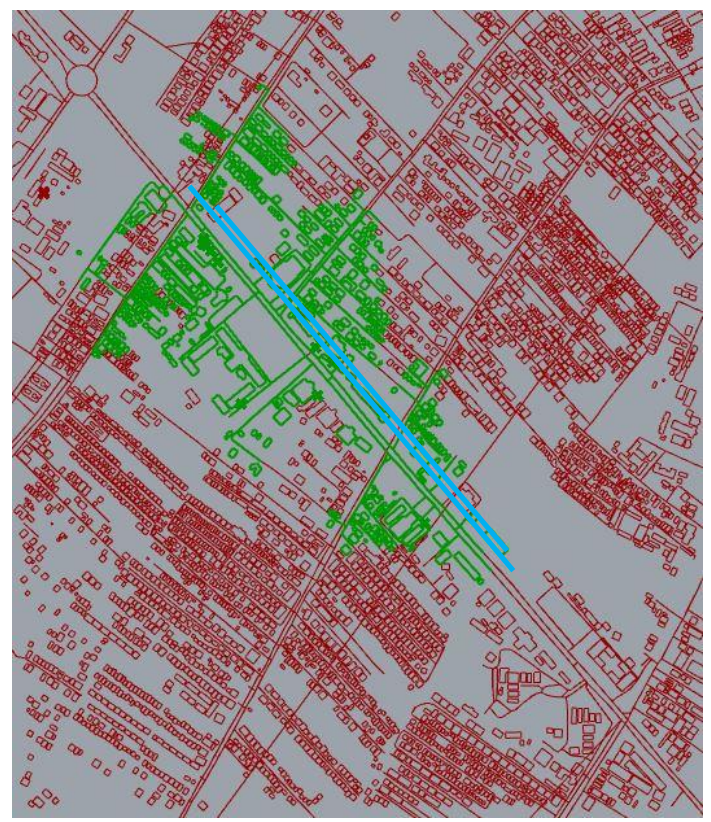

Sumber: (Analisis, 2021)

Gambar 15: Radius Perjalanan Segmen 3, Jarak Maksimum 500 meter

\section{Bangkitan Perjalanan}

Bangkitan perjalanan memperhitungkan jumlah pejalan kaki yang berpotensi menggunakan jalur pedestrian berdasarkan perjalanan jarak dekat antar bangunan atau aktivitas kegiatan layanan di kawasan 
tersebut. Gambar di bawah memperlihatkan jumlah pejalan kaki dan warna yang bermakna semakin merah (gelap) jalur pedestrian, maka jalur tersebut semakin ramai. Sebaliknya, semakin terang warna jalur/angka, maka jalur akan semakin sepi.

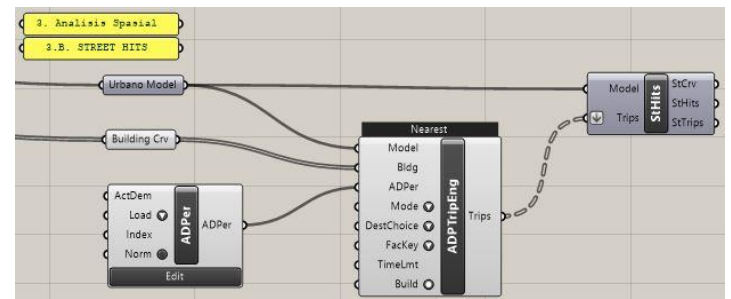

Sumber: (Analisis, 2021)

Gambar 16: Komponen/Parameter Street Hits

Segmen 2 merupakan jalur pedestrian yang berpotensi paling ramai dilalui oleh pejalan kaki. Titik pusat kegiatan pejalan kaki berada di sekitar area komersial (kompleks pusat perdagangan Ayani Mega Mall). Potensi maksimum jumlah pejalan kaki yang dapat diperkirakan akan beraktivitas di jalur pedestrian di bagian ini di antara 20.000 26.000 pejalan kaki dalam kurun waktu 12 jam atau kurang lebih 28 s.d. 36 pejalan kaki/menit. Berbeda dengan sisi depan kawasan pusat perbelanjaan Ayani Mega Mall, jalur pedestrian di bagian lain segmen ini terlihat memiliki potensi yang sangat rendah, berkisar $800-20.000$ pejalan kaki dalam waktu 12 jam atau 1 s.d. 28 pejalan kaki/menit. Khusus pada bagian utara Jalan Ahmad Yani, jalur pedestrian memiliki potensi maksimum 18 pejalan kaki/menit.

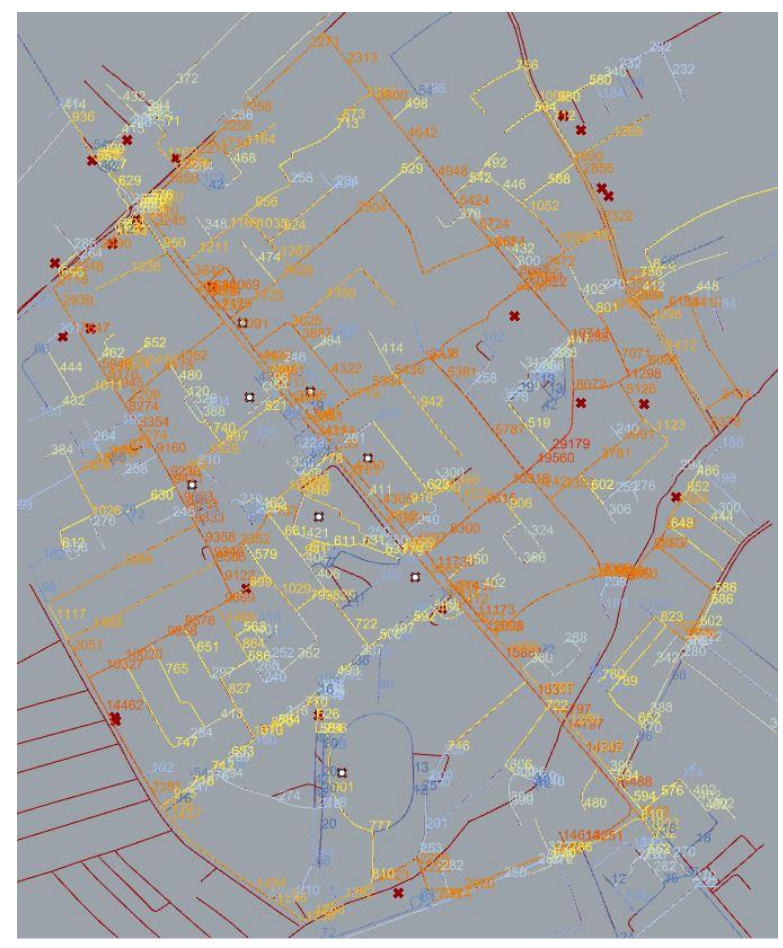

Sumber: (Analisis, 2021)

Gambar 17: Street Hits Segmen 1

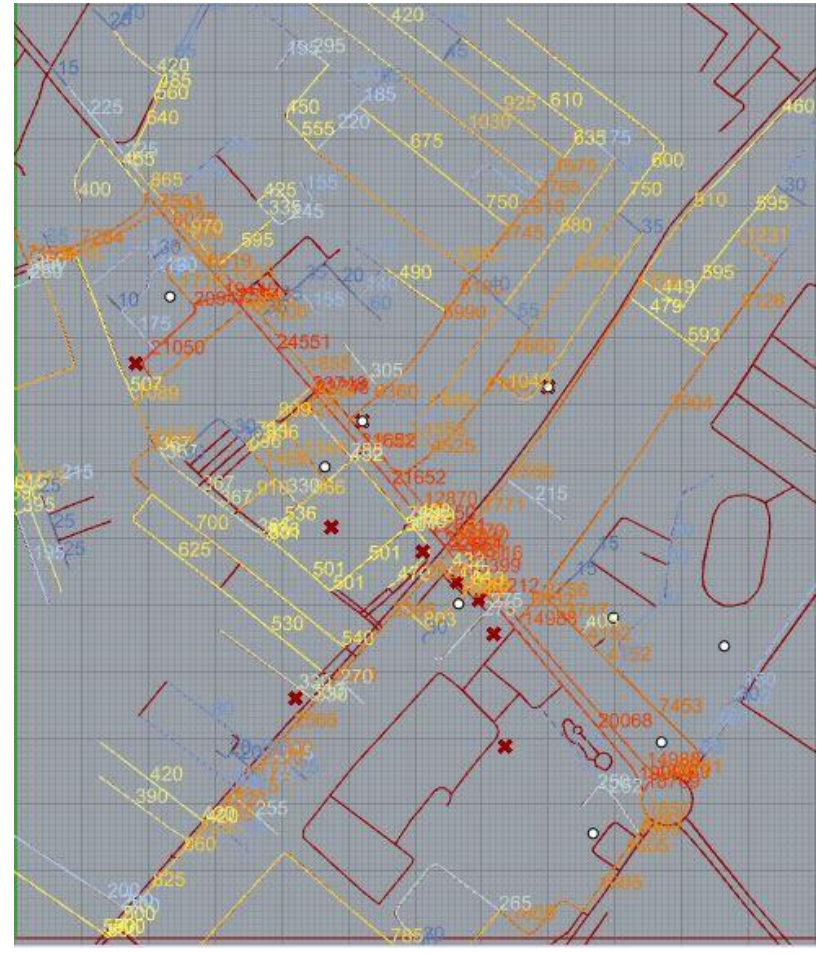

Sumber: (Analisis, 2021)

Gambar 18: Street Hits Segmen 2 


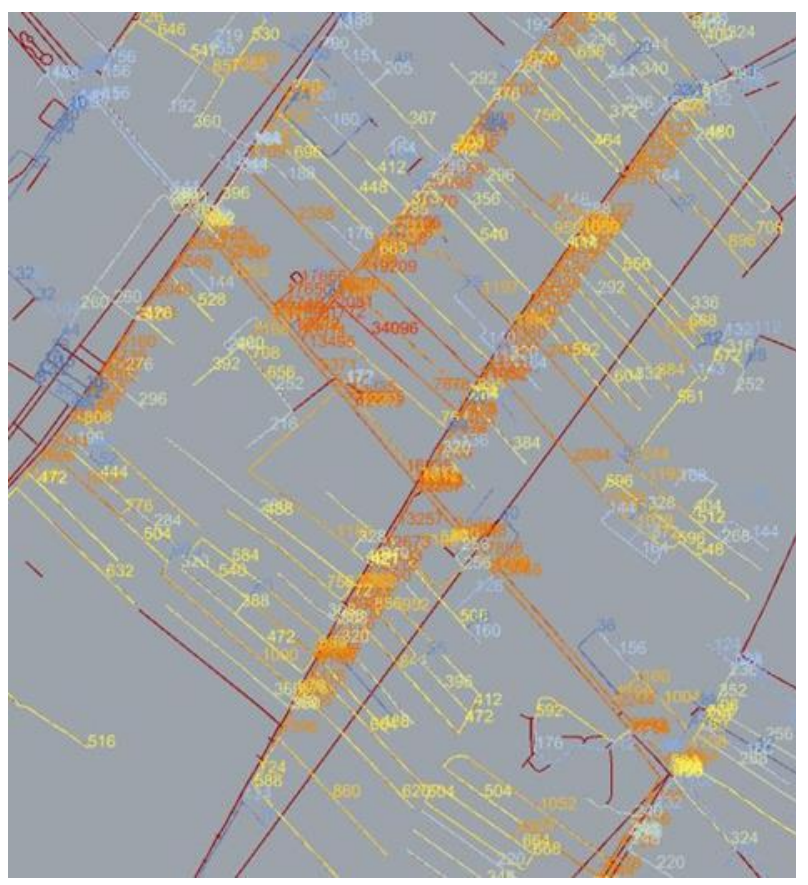

Sumber: (Analisis, 2021)

Gambar 19: Street Hits Segmen 3

Bangkitan pergerakan pejalan kaki cukup merata terlihat di Segmen 1. Walaupun terlihat terdapat rentang $900-16.000$ pejalan kaki, namun rata-rata potensi pejalan kaki berada di angka 3 s.d. 7 pejalan kaki/menit. Potensi penumpukan pergerakan pejalan kaki diprediksi berada di sisi selatan Jalan Ahmad Yani dekat area kawasan olah raga (GOR).

Di Segmen 3, potensi bangkitan kegiatan perjalanan kaki berkisar di antara 141 17.500 pejalan kaki atau sampai dengan 24 pejalan kaki/menit. Pemusatan kegiatan terlihat berada di sekitar simpang Jalan BLKI (sisi utara Jalan Ahmad Yani) dan simpang Jalan Parit H. Husin 2 (sisi selatan Jalan Ahmad Yani) dengan fungsi kawasan sekitar berupa fasilitas kesehatan dan dekat dengan beberapa rumah makan/restoran. Sedangkan pada bagian lain jalur pedestrian di segmen ini hanya memiliki potensi pergerakan 7 s.d. 9 pejalan kaki/menit.

\section{Walkscore}

Pengukuran walkscore didasarkan kepada metode perhitungan walkscore.com dari masing-masing bangunan. Skor peluang melakukan perjalanan dari masing-masing bangunan terlihat bahwa Segmen 1 memiliki peluang yang cukup tinggi, yaitu sampai dengan 24 dari 100. Walkscore di segmen 2 dan 3 relatif sama, yaitu sampai dengan 15 dari 100. Walaupun demikian Segmen 2 memiliki rata-rata walkscore yang paling rendah.

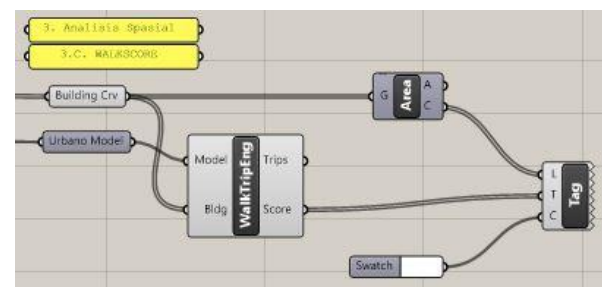

Sumber: (Analisis, 2021)

Gambar 20: Komponen/Parameter Walkscore

Keseragaman

angka

kemampuan/peluang melakukan pergerakan bagi pejalan kaki sangat dipengaruhi oleh kedekatan bangunan dengan fasilitas pelayanan perkotaan. Angka ini di bawah 25 dari 100 adalah nilai yang sangat rendah bagi membangkitkan pergerakan pejalan kaki atau aktivitas berjalan kaki bagi penghuni bangunan. Perbandingan beberapa kota di dunia yang memiliki peluang bangkitan pergerakan pejalan kaki yang tinggi dapat mencapai angka hingga di atas 70 dari 100.

Rendahnya angka ini sejalan dengan beberapa studi bangkitan pergerakan yang ada saat ini. Dari beberapa hasil studi pergerakan pejalan kaki di Jalur Pedestrian Jalan Ahmad Yani Kota Pontianak, diperoleh angka 1 s.d. 2 pejalan kaki/menit (Riani, Wulandari, \& Ayuningtyas, 2018). Angka 2 pejalan kaki/menit diperoleh di area yang terdapat fungsi perdagangan, peribadatan, dan fungsi pendidikan. Sedangkan di bagian ruas jalur pedestrian kurang dari 1 pejalan kaki/menit. Distribusi waktu juga terlihat hanya ramai di waktu sore hari di kawasan pendidikan dan komersial, atau siang hari di kawasan fungsi peribadatan. Angka 7 pejalan kaki/menit dapat tercapai pada hari minggu pagi, khususnya saat berlangsung car free day di kawasan di Segmen 1 dan Segmen 2. 


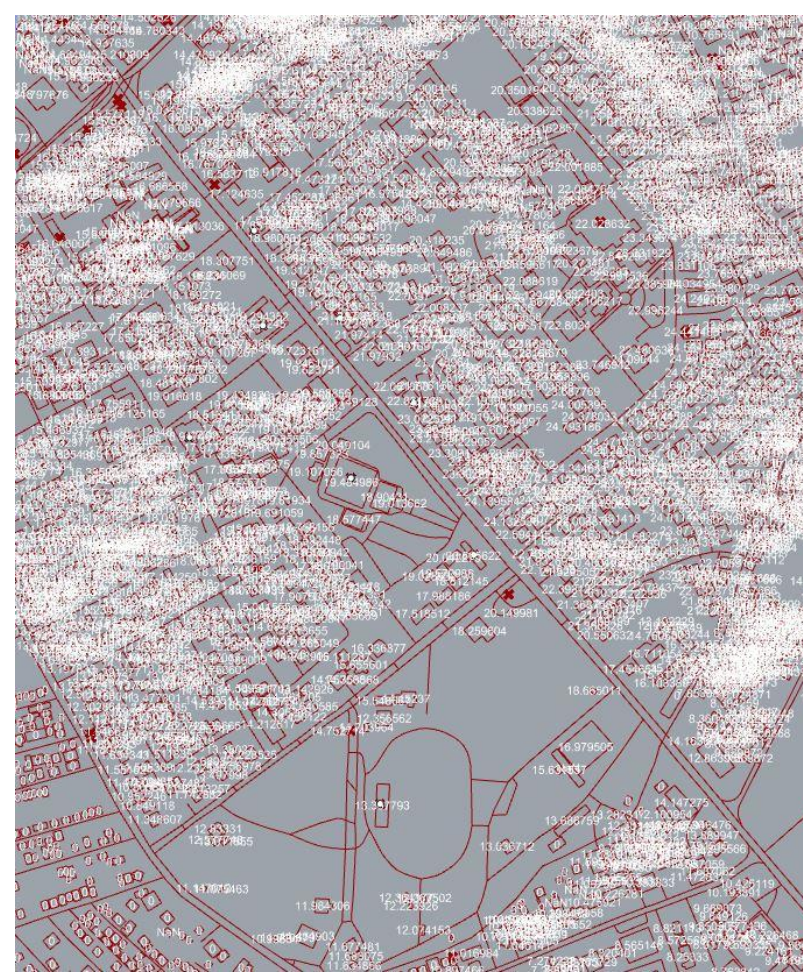

Sumber: (Analisis, 2021)

Gambar 21: Walkscore Segmen 1

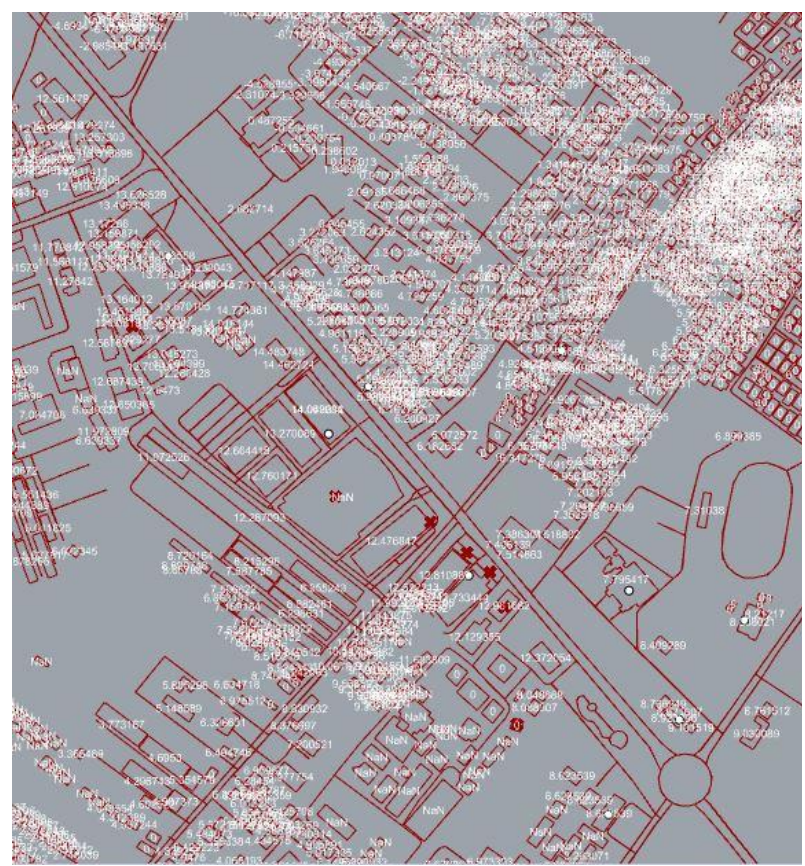

Sumber: (Analisis, 2021)

Gambar 22: Walkscore Segmen 2

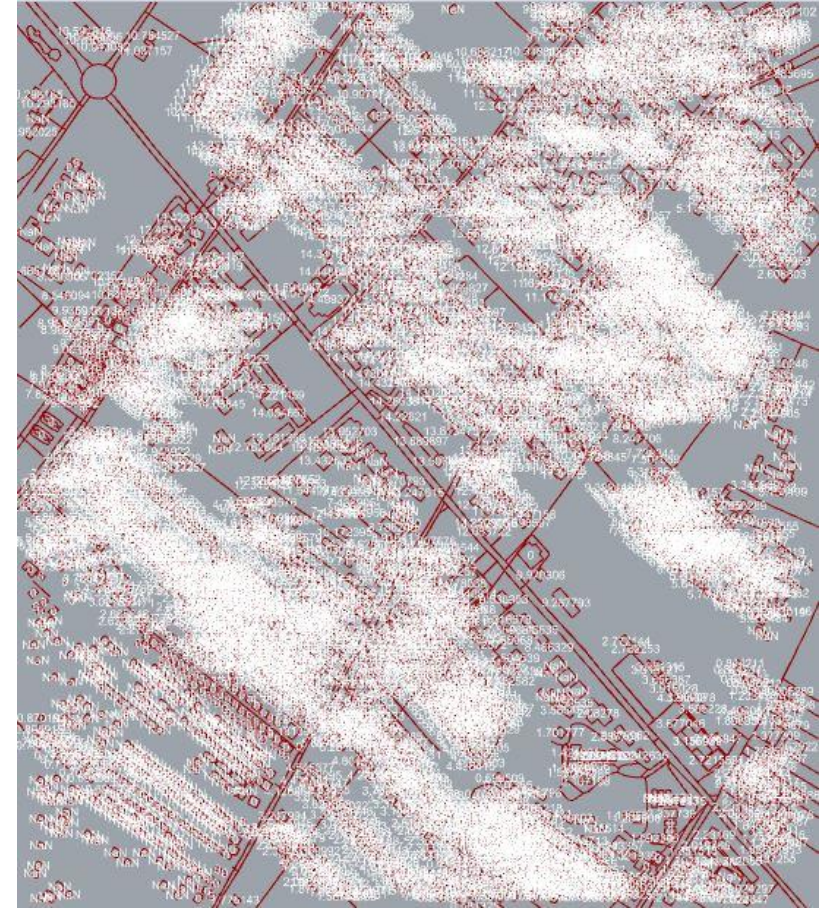

Sumber: (Analisis, 2021)

Gambar 23: Walkscore Segmen 3

\section{Optimasi Perencanaan Fasilitas Pejalan Kaki}

Potensi pergerakan berdasarkan analisis spasial cukup berbanding terbalik dengan kondisi eksisting di jalur pedestrian Jalan Ahmad Yani Kota Pontianak. Rendahnya minat masyarakat untuk melakukan kegiatan berjalan kaki di wilayah ini maupun di Kota Pontianak secara keseluruhan menjadi tantangan bagi pengelola kota untuk mencari titik optimum perencanaan. Saat ini potensi kegiatan yang dilakukan oleh masyarakat untuk memanfaatkan fasilitas jalur pejalan kaki lebih dominan untuk tujuan fungsional dan rekreatif, seperti kesehatan atau berolahraga, dibandingkan tujuan yang pragmatis. Sehingga dalam praktiknya, ruang bagi pejalan kaki ini lebih dimanfaatkan pada akhir minggu atau hari libur, baik di pagi hari atau di sore hari.

Banyak faktor yang menyebabkan rendahnya minat pejalan kaki di wilayah Kota Pontianak atau khususnya di Jalan Ahmad Yani. Beberapa faktor yang menjadi pertimbangan adalah faktor alamiah dan faktor buatan. Faktor alamiah seperti iklim tropis yang panas dan lembap menjadi salah 
satu tantangan tersendiri. Sedangkan untuk faktor buatan termasuk di dalamnya adalah rancangan fisik jalur pedestrian hingga faktor spasial dan kebijakan pengelolaan perkotaan, seperti perencanaan struktur dan pola ruang yang menunjang keberadaan jalur pedestrian.

Walaupun secara spasial, jalur pedestrian di Kawasan Jalan Ahmad Yani secara teoritis (spasial) bisa mencapai 36 pejalan kaki/menit, tetap dipengaruhi oleh kemauan orang untuk berjalan kaki (hasil penelitian memperlihatkan peluang yang cukup rendah, yaitu 24 dari 100). Optimasi perencanaan dan perancangan jalur pedestrian perlu dilakukan dengan mempertimbangkan banyak faktor di atas. Secara spasial penempatan fungsi-fungsi aktivitas yang cukup dibutuhkan oleh masyarakat menjadi kunci peningkatan pergerakan, seperti restoran/rumah makan, toko kebutuhan harian, fasilitas pendidikan, bank dan ATM, dan fasilitas lainnya (Lihat Tabel 1).

Ruang kota dengan fungsi layanan yang heterogen akan mendorong bangkitnya pergerakan pejalan kaki. Jarak jangkau maksimal 500 meter (sebaiknya kurang dari 200 meter) antara fungsi layanan dengan kawasan perkantoran juga perlu untuk diterapkan. Sehingga penambahan atau pencampuran aktivitas dan tata guna lahan di Jalan Ahmad Yani sebagai penunjang fungsi perkantoran dan pendidikan dapat dipertimbangkan untuk direncanakan di masa yang akan datang.

Selanjutnya tatanan fisik jalur pedestrian di sepanjang Jalan Ahmad Yani dapat direncanakan sesuai dengan kondisi iklim, potensi pergerakan dan persyaratan teknis lainnya. Keterbatasan ruang menjadi salah satu kendala perencanaan jalur pedestrian di perkotaan. Lebar jalur pedestrian dapat dipertimbangkan terhadap potensi pergerakan yang ada, sehingga jalur yang direncanakan menjadi tepat sasaran. Seperti jalur pedestrian dengan lebar efektif jalur pedestrian sebesar 1,5 meter atau total lebar 2,5 meter (termasuk kerb, jalur fasilitas, jalur pedestrian dan bagian depan gedung) sebagaimana diatur dalam Tabel 4 dan
Rumus 1 sudah mencukupi bangkitan pergerakan maksimum yang ada. Selain itu perencanaan lebar efektif 0,75 meter berdasarkan hasil kajian ini (pergerakan di bawah 10 pejalan kaki/menit) sudah mencukupi bangkitan pergerakan yang ada di sebagian besar ruas Jalan Ahmad Yani, sehingga jika masih terdapat sisa ruang, dapat dimanfaatkan sebagai ruang hijau/jalur hijau.

Keberadaan jalur hijau di jalur pedestrian dan jalan raya menjadi salah satu solusi terhadap iklim yang ada di Kota Pontianak, di samping fungsinya untuk mereduksi polusi udara. Keberadaan vegetasi-vegetasi, khususnya dengan tajuk dan fungsi peneduh dapat memberikan kenyamanan bagi pejalan kaki.

Kebijakan pengelolaan perkotaan di bidang transportasi yang mendukung keberadaan jalur pedestrian juga sangat diperlukan. Salah satu tujuan orang berjalan kaki adalah adanya peralihan moda transportasi. Keberadaan sistem angkutan umum yang baik sangat diperlukan untuk mendorong bangkitnya pergerakan pejalan kaki. Penempatan simpul-simpul peralihan moda transportasi seperti halte, khususnya di wilayah dekat untuk fungsi komersial, pendidikan dan perkantoran, perlu direncanakan dalam konteks integrasi sistem transportasi perkotaan di Kota Pontianak.

\section{KESIMPULAN}

Hasil analisis memperlihatkan bahwa berdasarkan kondisi spasial saat ini di sepanjang Jalan Ahmad Yani, masih kurang mendukung bangkitan kegiatan pejalan kaki. Hal ini dapat terlihat dari rendahnya intensitas bangunan di sepanjang kawasan, walaupun kawasan berada di sepanjang utama atau jalan arteri Kota Pontianak. Selain itu sebaran aktivitas kegiatan pelayanan masih dirasakan belum merata, khususnya dalam jangkauan kemampuan seseorang berjalan kaki (walkability). Distribusi dan sebaran fasilitas terlihat belum merata atau tingkat heterogen dari fungsi-fungsi yang dibutuhkan oleh masyarakat belum terencana 
dan mendukung peningkatan bangkitan pergerakan pejalan kaki.

Sebagai penelitian deskriptif, penelitian ini masih perlu untuk dilakukan pendalaman atau eksplanatif. Penelitian menggunakan atribut standar dari aplikasi dan atau bersifat normatif serta masih perlu dilakukan penelitian lanjutan, seperti memasukkan nilai bangkitan pejalan kaki untuk masing-masing aktivitas/bangunan di Kota Pontianak, pembaruan metadata terkini beberapa komponen penelitian, dan detail-detail lainnya. Selanjutnya kajian optimasi terhadap potensi jalur pejalan kaki dalam perencanaan tata ruang wilayah perkotaan perlu untuk dilakukan.

\section{UCAPAN TERIMA KASIH}

Ucapan terima kasih penulis sampaikan kepada seluruh tim peneliti dan seluruh pihak yang telah membantu penyelesaian penelitian dan penulisan artikel ini. Tidak lupa penulis ucapkan terima kasih kepada Panitia Seminar Nasional VI 2021 Untan, yang telah memungkinkan naskah ini dapat dipublikasikan dalam forum dan jurnal ilmiah.

\section{DAFTAR PUSTAKA}

Bungin, B. (2010). Penelitian Kualitatif: Komunikasi, Ekonomi, Kebijakan Publik, dan Ilmu Sosial Lainnya. Jakarta: Kencana Prenad Media Group.

Dogan, T., Samaranayake, S., \& Saraf, N. (2018). Urbano: a New Tool to Promote Mobility-aware Urban Design, Active Transportation Modeling and Access Analysis for Amenities and Public Transport. SIMAUD '18: Proceedings of the Symposium on Simulation for Architecture and Urban Design (hal. 273-280). San Diego: Society for Computer Simulation International.

Dogan, T., Yang, Y., Samaranayake, S., \& Saraf, N. (2020). Urbano: A Tool to
Promote Active Mobility Modeling and Amenity Analysis in Urban Design. Technology|Architecture + Design, 4(1), 92-105.

Galingan, Z. C., Alcazaren, P. G., Ramos, G. C., \& Santos, R. B. (2009). Pedestrian-Friendly Streetscape in a Tropical Business District. Muhon: a Journal of Architecture, Landscape Architecture, and the Designed Environment(3), 9-15.

Morissan, Corry, A., \& Hamid, F. (2012). Metode Penelitian Survei. Jakarta: Kencana Prenada Media Group.

Perencaaan Teknis Fasilitas Pejalan Kaki, SE Menteri PUPR No.02/SE/M/2018 (Kementerian Pekerjaan Umum dan Perumahan Rakyat 2 26, 2018).

Region, P. a. (2021, 7 12). Sandag. Diambil kembali dari www.sandag.org: www.sandag.org/uploads/publication id/publicationid_713_3269.pdf

Riani, Y. H., Wulandari, A., \& Ayuningtyas, R. A. (2018). Evaluasi Efektivitas Jalur Pedestrian di Jalan Ahmad Yani Kota Pontianak Berdasarkan Persepsi Masyarakat. JeLAST: Jurnal PWK, Laut, SIpil, Tambang, 5(3), 1-12.

Rudito, B., \& Famiola, M. (2013). Social Mapping: Metode Pemetaan Sosial, Teknik Memahami Suatu Masyarakat atau Komuniti. Bandung: Rekayasa Sains.

Sakinah, R., Kusuma, H. E., Tampubolon, A. C., \& Prakarso, B. (2018). Kriteria Jalur Pedestrian di Indonesia. Jurnal Lingkungan Binaan Indonesia, 7(2), 81-85.

Shaban, K., \& Muley, D. (2016). Investigation of Weather Impacts on Pedestrian Volumes. Transportation Research Peocedia, 14, 115-122. 
Shirvani, H. (1985). The Urban Design Process. New York: Van Nostrand Reinhold.

Tanan, N. (2011). Fasilitas Pejalan Kaki. Jakarta: Kementerian Pekerjaan Umum.

Tisnaningtyas, E. Y. (2015). Aspek Kenyamanan Pejakan Kaki Terhadap Iklim Tropis dan Aksesibilitas Pejalan Kaki di Lapangan Kota Sebagai
Kawasan Pedestrian. Neo Teknika: Jurnal Ilmiah Teknologi, 1(2), 54-62.

Wardhono, U. P. (2009). Glosari Arsitektur: Kamus Istilah dalam Arsitektur. Yogyakarta: Penerbit ANDI.

Weber, R., Tammi, I., Anderson, T., \& Wang, S. (2016). A Spatial Analysis of CityRegions: Urban Form \& Service Accessibility. Stockholm: Nordregio. 
Bidang Lingkungan Binaan dan Rekayasa 